\title{
A Study on the Evolution and Development Characteristics of China Producer Service Agglomeration
}

\author{
Fei Chen \\ South China University of Technology \\ Guangzhou, China
}

\begin{abstract}
This paper used Herfindahl-Hirschman Index, Ellision-Glaeser Index and Location Quotient to measure the market agglomeration degree, industry agglomeration degree and regional agglomeration degree of producer service and its inner industrials of China. On this basis, under the guide of service economics theory, this article summarized the evolution characteristics of China producer service agglomeration and then put forward some corresponding policy suggestion. Main conclusions included: agglomeration degree of producer services continued to increase; knowledge-intensive producer services tended to cluster in the center of large cities and the agglomeration degrees continuously strengthened; "backoffice" producer services transferred from east region to central and west region and agglomerated at that area; financial industry tended to agglomeration and dispersion coexist.
\end{abstract}

Keywords-producer service; evolution; development characteristics

\section{INTRODUCTION}

Since 1950s, the effect of producer services in the field of production has been changed continuously, from management function (acting as lubricant) to promotional function (acting as productive forces), and finally turns to strategic function (acting as thrusters) [1]. Under the hard constraints of resources and environment, it is significant for promoting the transition of economic development patterns, accelerating the development of producer service and realizing the fusion of manufacturing industry and service industry effectively by producer services agglomeration. Since 1970s, academia has started to pay attention to phenomena of producer services agglomeration. Early scholars focused on motivations of these phenomena, and, from their opinions, motivations are improving corporate reputation [3][4], responding to economic uncertainty, reducing risk [5], being close to the customer, affiliated enterprises, other service enterprises [2] and so forth. In the meantime, there were scholars who concerned effects of producer services agglomeration, such as learning effects [6], social and cultural effects [7], and spillover effects [8] in industry and so on. In recent years, related researches mainly focus on the influence factors of agglomeration. For instance, such as Jianjun Chen (2009) indicated that knowledge intensity, information technology level, the scale of government and city all have great effects on agglomeration [9]; Yunsheng Gao (2006) studied the influence on agglomeration from production factors, location, demand, regime and environment [10]. In the empirical study of producer services agglomeration, scholars used spatial Gini Coefficient [12], Herfindahl-Hirschman Index [13] and Location Quotient [11] to measure the concentration degree of producer services.

\section{METhODOlOGY AND DATA}

\section{A. Definition of the Extension of Producer Services}

The definition of the extension of producer services is complicated and controversial. Until now, lots of scholars tended to focus the studies on some specific producer services sectors [14]. Therefore, in view of the connotation of producer services and availability of data, this paper represented producer service with transportation, warehousing, post and telecommunication industry (TWPTI), information transmission, computer service and software industry (ICSI), financial industry (FI), leasing and business service industry (LBI), scientific research, technology service and geological prospecting industry (STGI).

\section{B. Ascertainment of the Agglomeration Degree Index of Producer Services}

Until now, more commonly used indexes to measure the concentration degree of industry are concentration ratio, GIndex, Herfindahl-Hirschman Index, CAD Index, Location Quotient Index, spatial Gini Coefficient, EG Concentration Index and so on. Each of these indexes has its own advantages and disadvantages. On the occasion that data was limited, in order to restore the full picture of agglomeration of China producer services, this paper chose HerfindahlHirschman Index to measure the market concentration degree of China producer service, then, chose EG Concentration Index to measure the industry concentration degree, and finally, used Location Quotient Index to measure the regional concentration degree. 
There has

$$
H i=\sum_{j=1}^{r} \frac{1}{N_{i j}} S_{i j}^{2}
$$

$\mathrm{Nij}$ is the number of enterprises in i industry, that located in the $\mathrm{j}$ area. OUTPUTij is the number of employees in $\mathrm{i}$ industry, that located in $\mathrm{j}$ area. OUTPUTi is the number of employees in i industry in China. Sij is the proportion of the number of employees within i industry that located in $\mathrm{j}$ area compared to the number of employees in i industry in China. Formula (4) is not as accurate as the method which used by Ellision and Glaeser, but it does not hinder us to evaluate and compare the industry concentration degree.

According to the formula (4), this paper measured the market concentration degree of China producer services and its inner industries, which could be illustrated by "Fig. 1".

Firstly, Herfindahl-Hirschman Index of China producer services and its inner industries were extremely small. It stated that the market concentration degree was really low and almost no enterprise had the ability to hold a monopoly in this industry. Secondly, comparing with others, the financial industry had a higher market concentration degree. In 2011, Hi of financial industry was 0.0000219 , which was 3.9 times as large as Hi of TWPTI, 3.4 times as large as Hi of ICSI, 12.4 times as large as Hi of LBI, and 5.3 times as large as Hi of STGI. It stated that state-owned commercial banks of China held some level of monopoly in staff, institutions, number of branches, loans, capital scale and market share. Thirdly, as a tendency, Hi of these inner industries of China producer services has dropped by different degrees. From 2004 to 2010, Hi of TWPTI has dropped by $14 \%$, similarly, $14.5 \%$ for ICSI, $15.4 \%$ for FI, $13.9 \%$ for LBI, and $10.5 \%$ for STGI. Because of regime and policy, China producer services were kind of hard-to-get-into, and also had lower market-based degree, and higher monopoly powers. For instance, the post office, the railway authority, state-owned commercial banks, China Telecom and so on. With acceleration of the reform of regime of management and property in these monopolized industries, more and more private enterprises, corporate enterprises and overseas-funded enterprises got into the field of producer service by participation, holdings, buyout, leasing and so on. More market entities and fiercer market competition made lower market concentration degree of producer services.

$$
\begin{aligned}
& H_{i}=\sum_{j=1}^{r} N_{i j}\left[\frac{\text { OUTPUT }_{i j} / N_{i j}}{\text { OUTPUT }_{i}}\right]^{2}=\sum_{j=1}^{r} \frac{1}{N_{i j}}\left[\frac{\text { OUTPUT }_{i j}}{\text { OUTPUT }_{i}}\right]^{2} \\
& \text { If } S_{i j}=\frac{\text { OUTPUT }_{i j}}{\text { OUTPUT }_{i}}
\end{aligned}
$$

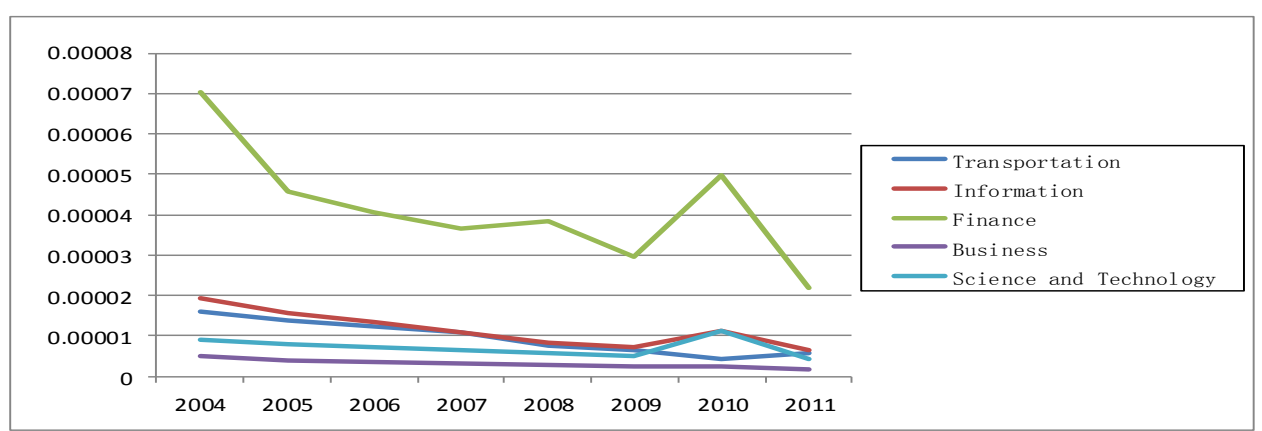

Fig. 1. Herfindahl-Hirschman index tendency of China producer services. (Data source: graphing calculating data from this paper) 
$\mathrm{Yi}$ is EG Concentration Index. $\mathrm{Gi}$ is spatial Gini coefficient. $\mathrm{Hi}$ is Herfindahl-Hirschman Index. $\mathrm{Xj}$ is the proportion of the number of employees of every industry in $j$ area in the number of employees in China. Sij is the proportion of the number of employees of every enterprise as above in the number of employees in $\mathrm{i}$ industry in China. The higher the value of $\mathrm{Yi}$ is, the higher concentration degree of a certain industry is. Whereas: the lower the value of $\mathrm{Yi}$ is, the lower concentration degree is.

According to the formula (5), this paper measured concentration degree of China producer services from 2004 to 2011. It can be illustrated by "Table I". We can summarize the evolution route and development characteristic as follows:

TABLE I. EG INDEX OF CHINA PRODUCER SERVICE

\begin{tabular}{|c|c|c|c|c|c|}
\hline Year & 1 & 2 & 3 & 4 & 5 \\
\hline 2004 & 0.001979 & 0.014978 & 0.000883 & 0.038707 & 0.011064 \\
\hline 2005 & 0.002514 & 0.01645 & 0.00125 & 0.037774 & 0.012683 \\
\hline 2006 & 0.003109 & 0.018115 & 0.001426 & 0.037342 & 0.013907 \\
\hline 2007 & 0.003491 & 0.027184 & 0.001081 & 0.04153 & 0.016409 \\
\hline 2008 & 0.003726 & 0.03183 & 0.001055 & 0.041507 & 0.018776 \\
\hline 2009 & 0.003707 & 0.030395 & 0.000933 & 0.049549 & 0.020177 \\
\hline 2010 & 0.217896 & 0.048834 & 0.757791 & 0.049266 & 0.043764 \\
\hline 2011 & 0.004463 & 0.038936 & 0.00147 & 0.033441 & 0.019976 \\
\hline Rate(\%) & 12.32 & 14.62 & 7.54 & -2.07 & 8.81 \\
\hline
\end{tabular}

a. Data source: calculating data from Chinese basic unit statistical yearbook

b. Note: "1" represents transportation, warehousing and mail industry. "2" represents information transmission, computer service and software industry. "3" represents financial industry. "4" represents leasing and business service industry. "5" represents scientific research, technical service and geological prospecting industry. "Rate" represents annual growth rate.

Firstly, for the general trend, concentration degree of China producer services was escalating. All industries, except LBI, demonstrated growth, albeit from varying volume levels. TWPTI enjoyed annual growth rate of $38 \%$. ICSI enjoyed annual growth rate of $14.62 \%$. FI enjoyed annual growth rate of $7.54 \%$. STGI enjoyed annual growth rate of $8.81 \%$. The concentration degree of China's manufacturing sector was relatively high. Manufacturing sector provided customized services, new information, professional technology and knowledge to manufacturing enterprises, so the agglomeration of China manufacturing sector benefited itself from being close to the customer, affiliated enterprises, other service industries and the agglomeration of decision makers. Geographic concentration of manufacturing industry always caused the approach of social culture. Thus, enterprises shared common value, belief, acquiescent understanding, and then depended upon each other non-transactional. The approach of social culture made enterprises mutually rewarding. Secondly, LBI enjoyed highest concentration degree. In 2011, the EG Concentration Index of LBI was 0.033, which was 7.5 times as large as that of TWPTI, 0.9 times as large as that of ICSI, 22.8 times as large as of FI, and 1.7 times as large as of STGI. The reason why LBI enjoyed high concentration degree could be concluded as follows: first, it was the underlying characteristic of this industry. Most professional services were positioned according to service requesters, so service suppliers had to go to customer locations to provide services. Although the development of information technology made the separation of business services and service demanders possible, but frequent interactions between suppliers and demanders are necessary for the spread of knowledge and creation of new knowledge. By communicating and cooperating with clients, suppliers realized and identified problems, present, control and assess solutions. Through the repetitive communication, the value of professional services was magnified and enhanced. Second, it was the essential factor. Services provided by business service industry were based on knowledge, technology and information. Thus, compared with other traditional service industries, neighboring schools and scientific research institutions to gain professional, high-quality talents was essential for business service industry to choose its location. Third, it was building corporate image. Human factors, such as traditions and prestige, accelerated the agglomeration of offices of producer service enterprises towards central business district of big cities, in order to build upscale corporate image. Actually, being located in famous service industry clusters was conducive for business service enterprises to improve their prestige and image [4].

Thirdly, the concentration degree of financial industry was the lowest. The concentration of financial industry meant a kind of special industrial spatial structure that institutions could work as headquarters, such as state financial regulatory, financial intermediaries, multinational financial enterprises, domestic financial enterprises, agglomerated on certain area, and kept in touch with other 


\section{The Measure of the Regional Concentration Degree of China Producer Services}

Location Quotient was originally proposed by P. Haggett, and used to measure the relatively regional concentration degree of certain part of an industry in special region. The formula is:

$$
\mathrm{LQ}=\mathrm{Aij} / \mathrm{Bij}
$$

Aij is the proportion of the number of employees of $i$ industry in $\mathrm{j}$ area in the number of employees in $\mathrm{j}$ area. Bij is the proportion of the number of employees of $i$ industry in the number of employees in the whole area. The higher the value of Location Quotient is, the higher the concentration degree is. Generally, when the value is 1 , it means this industry tends to concentrate. When the value is bigger than 1.5 , it means this industry has apparently agglomerated. Considering particular situations in China, this paper regarded the value that bigger than 1.2 as the sign of apparent agglomeration.

According to the formula (7), this paper measured the regional concentration degree of China producer services. It can be illustrated by "Table II". more and more business outlets will be located in urban areas in order to offer face-to-face services. In the long term, the location of financial branches tends to be more dispersive, and the concentration degree trends downward.

Fourthly, the concentration degree of ICSI rose the most rapidly. In 2004, the EG Concentration Index of ICSI was 0.015 . Although it ranked second, compared with LBI (0.038), it was not as much as half of the latter. In 2010, the EG Concentration Index of ICSI rose to 0.0488 . Though it was still lower than the index of LBI (0.0492), the gap was very narrower. In 2011, the EG Concentration Index of ICSI was a little lower than the index of 2010, with the number of 0.038 and the annual growth of $14.62 \%$, but it became the industry that enjoyed the highest concentration degree, higher than the 0.033 of LBI. The reasons why the concentration degree of ICSI rose rapidly are as follows: on the one side, it was the nature of this industry. Information transmission, computer service and software industry highly depended on knowledge and information, so career men of this field had to learn the latest technology and information to update their knowledge structure and professional skills. Thus, it was more convenient for enterprises to communicate with counterparts and acquire new knowledge, be close to customer to accelerate the spread and transfer of tacit knowledge, inset social capital to increase mobility of technical information and knowledge in order to reduce transaction costs, reduce costs of finding talents and so on by locating near institutions of higher education, scientific research institutions and large urban centers. On the other side, policies also promoted the concentration of information service industry. In the recent years, Chinese government increased the support strength on information service industry by successively making a series of new policies to advance development of information service industry, and local governments established software industry bases, created favorable policies and measured to agglomerate information service industry. 
TABLE II. LOCATION QUOTIENT OF EVERY PROVINCE

\begin{tabular}{|c|c|c|c|c|c|c|c|c|c|c|c|c|c|c|c|}
\hline & 1 & 2 & 3 & 4 & 5 & 1 & 2 & 3 & 4 & 5 & 1 & 2 & 3 & 4 & 5 \\
\hline & & & 2004 & & & & & 2007 & & & & & 2011 & & \\
\hline Beijing & 1.2 & $\underline{3.5}$ & 0.8 & 5.2 & 2.8 & 1.6 & 4.3 & 1.2 & 5.0 & 3.2 & 1.8 & 4.8 & 1.4 & 4.3 & 3.6 \\
\hline Tianjin & $\overline{1.2}$ & $\overline{1.0}$ & 0.8 & $\overline{1.3}$ & $\overline{1.4}$ & $\overline{1.2}$ & $\overline{1.0}$ & $\overline{0.9}$ & $\overline{1.7}$ & $\overline{1.4}$ & $\overline{0.9}$ & $\overline{0.5}$ & $\overline{0.8}$ & $\overline{1.2}$ & $\overline{1.0}$ \\
\hline Hebei & $\overline{0.9}$ & 0.9 & 1.1 & 0.5 & 0.8 & 1.0 & 0.9 & 1.2 & 0.5 & 0.7 & 1.0 & 0.7 & 1.2 & 0.5 & 0.9 \\
\hline Liaoning & 1.2 & 0.9 & 1.1 & 0.9 & 0.9 & 1.3 & 0.9 & 1.2 & 1.0 & 1.0 & 1.2 & 1.0 & $\overline{1.1}$ & 1.1 & 1.2 \\
\hline Shanghai & 1.8 & 1.1 & 1.5 & 2.3 & 1.9 & 1.7 & 1.1 & 1.6 & 2.4 & 2.1 & 1.8 & 1.1 & 1.6 & 1.9 & 1.2 \\
\hline Jiangsu & $\overline{1.0}$ & 0.9 & $\overline{1.0}$ & $\overline{0.8}$ & 0.7 & $\overline{0.9}$ & 0.8 & $\overline{1.0}$ & $\overline{0.6}$ & $\overline{0.6}$ & $\overline{0.8}$ & 0.8 & $\overline{1.0}$ & $\overline{0.7}$ & $\overline{0.7}$ \\
\hline Zhejiang & 0.8 & 1.0 & 1.3 & 1.5 & 0.7 & 0.6 & 0.9 & 1.0 & 1.2 & 0.7 & 0.6 & 0.9 & 0.9 & 1.4 & 0.8 \\
\hline Fujian & 0.7 & 0.7 & 0.8 & 0.7 & 0.5 & 0.6 & 0.7 & 0.7 & 0.7 & 0.5 & 0.7 & 0.6 & 0.7 & 0.6 & 0.5 \\
\hline Shandong & 0.7 & 0.6 & 0.9 & 0.6 & 0.5 & 0.7 & 0.5 & 0.9 & 0.6 & 0.5 & 0.7 & 0.5 & 0.9 & 0.5 & 0.5 \\
\hline Guangdong & 1.0 & 1.4 & 1.2 & 1.2 & 0.6 & 0.9 & 1.3 & 1.0 & 1.3 & 0.7 & 1.1 & 1.1 & 1.1 & 1.3 & 0.7 \\
\hline Guangxi & 1.1 & 0.9 & 1.0 & 1.2 & 0.9 & 1.2 & 0.9 & 0.9 & 1.1 & 1.0 & 1.2 & 0.8 & 0.9 & 1.4 & 1.1 \\
\hline Hainan & 1.0 & 0.9 & 0.9 & $\overline{1.0}$ & 1.0 & 1.0 & 0.8 & 0.8 & 1.3 & 1.1 & 1.2 & 0.8 & 0.8 & 1.4 & 0.9 \\
\hline Shanxi & 1.0 & 0.8 & 0.9 & 0.7 & 0.8 & 1.2 & 0.9 & 1.1 & 0.8 & 0.8 & 1.2 & 0.8 & 1.0 & 0.7 & 0.7 \\
\hline $\begin{array}{l}\text { Inner } \\
\text { Mongolia }\end{array}$ & 1.2 & 1.1 & 1.1 & 0.7 & 0.9 & 1.2 & 1.2 & 1.1 & 0.5 & 0.8 & 1.4 & 1.1 & 1.1 & 0.6 & 0.8 \\
\hline Jilin & $\overline{1.5}$ & 0.9 & 1.1 & 0.8 & 1.1 & $\overline{1.2}$ & $\overline{1.0}$ & 1.1 & 0.6 & 1.2 & $\overline{1.1}$ & 1.4 & 1.1 & 0.8 & 1.2 \\
\hline Heilongjiang & 1.1 & 0.8 & 0.7 & 0.6 & 0.9 & 1.0 & 0.8 & 0.7 & 0.4 & 1.0 & 1.2 & 0.9 & 0.9 & 0.5 & 1.3 \\
\hline Anhui & 0.9 & 0.7 & 1.0 & 0.6 & 0.8 & 0.9 & 0.8 & 1.1 & 0.8 & 0.8 & 0.9 & 0.7 & 1.1 & 0.6 & 0.9 \\
\hline Jiangxi & 1.0 & 0.9 & 1.0 & 0.4 & 1.0 & 1.1 & 0.9 & 0.9 & 0.4 & 0.9 & 0.9 & 0.6 & 0.9 & 0.5 & 0.8 \\
\hline Henan & 0.9 & 0.6 & 0.9 & 0.8 & 0.8 & 0.8 & 0.5 & 1.0 & 0.7 & 0.8 & 0.8 & 0.5 & 0.8 & 0.7 & 0.7 \\
\hline Hubei & 1.1 & 0.7 & 0.9 & 0.9 & 1.0 & 1.3 & 0.7 & 1.0 & 0.5 & 1.0 & 0.9 & 0.7 & 0.8 & 0.4 & 1.0 \\
\hline Hunan & 1.1 & 1.0 & 1.1 & 0.8 & 0.8 & $\overline{1.0}$ & 0.8 & 1.1 & 0.6 & 0.7 & 0.9 & 0.8 & 1.1 & 0.8 & 0.7 \\
\hline Chongqing & 1.2 & 1.0 & 0.9 & 0.4 & 1.4 & 1.1 & 0.9 & 1.1 & 0.8 & 1.1 & 1.0 & 0.8 & 1.0 & 0.9 & 0.7 \\
\hline Sichuan & 0.8 & 0.9 & 1.0 & 0.4 & 1.3 & 0.9 & 0.7 & 1.0 & 0.5 & 1.1 & 0.8 & 0.7 & 1.0 & 0.5 & 1.2 \\
\hline Guizhou & 0.8 & 1.0 & 0.8 & 0.8 & 0.8 & 0.8 & 0.8 & 0.8 & 0.7 & 0.9 & 0.9 & 0.8 & 0.8 & 0.7 & 0.9 \\
\hline Yunnan & 0.9 & 1.2 & 1.1 & 0.6 & 1.1 & 0.8 & 1.0 & 0.8 & 0.8 & 1.0 & 0.8 & 0.8 & 0.8 & 1.0 & 0.9 \\
\hline Xizang & 0.7 & 1.5 & 1.5 & 0.0 & 1.7 & 0.8 & 1.5 & 1.1 & 0.4 & 1.4 & 0.6 & 0.6 & 1.1 & 0.3 & 1.5 \\
\hline Shaanxi & 1.1 & $\overline{0.8}$ & $\overline{1.0}$ & 0.6 & 1.9 & 1.1 & 0.8 & 0.9 & 0.4 & 1.8 & 1.1 & 1.3 & 1.0 & 0.5 & $\overline{1.8}$ \\
\hline Gansu & 1.2 & 1.0 & 1.0 & 0.6 & $\overline{1.3}$ & 1.0 & 0.7 & 1.0 & 0.6 & $\overline{1.3}$ & 1.1 & $\overline{0.6}$ & 1.0 & 0.5 & $\overline{1.2}$ \\
\hline Qinghai & 1.5 & 1.6 & 1.1 & 0.7 & $\overline{2.4}$ & 1.4 & 1.5 & 1.0 & 0.9 & $\overline{1.8}$ & 1.2 & 1.0 & 0.9 & 0.7 & $\overline{2.1}$ \\
\hline Ningxia & $\overline{0.9}$ & $\overline{0.9}$ & 1.1 & 0.5 & $\overline{1.0}$ & $\overline{0.9}$ & $\overline{0.7}$ & 1.4 & 0.7 & $\overline{1.0}$ & $\overline{1.1}$ & 0.7 & 1.3 & 1.2 & $\overline{1.0}$ \\
\hline Xinjiang & 0.8 & 0.7 & 0.9 & 0.9 & 1.0 & 0.9 & 0.6 & $\overline{0.8}$ & 1.0 & 0.9 & 1.0 & 0.6 & $\overline{0.8}$ & $\overline{1.0}$ & 0.9 \\
\hline
\end{tabular}

Note: limited by space, this paper only lists results of several years. The underlined number is bigger than 1.2. "1" represents transportation. "2" represents information. "3" represents finance. "4" represents business. "5" represents science and technology.

b. Data source: calculating data from Chinese basic unit statistical yearbook.

Firstly, from the static index, the concentration degree of produce services in the east was obviously higher than it in the middle and west. Beijing enjoyed the highest concentration degree, and five inner trades of producer services were all highly agglomerated, especially, ICSI and LBI that respectively enjoyed the value of 4.8 and 4.3 that was much higher than other provinces at the same time. In addition, the concentration degree of Shanghai was comparatively high as well, except the ICSI, the value of all the other industries was higher than 1.2. While, for the middle and west, every province showed no sign of agglomeration, especially LBI, FI, ICSI. From 2004 to 2011, except several provinces, there was hardly an area that reached the level of 1.2. It means that producer services, especially LBI, FI, ICSI, obviously has shown agglomeration towards large urban centers. Remarkably, although almost all areas with the Location Quotient more than 1.2 agglomerated in the east, the gaps of Location Quotient of all the provinces and autonomous regions in China were not that large. Shanghai with the highest value of 1.6 and Heilongjiang with the lowest value of 0.7 , financial industry in all the other areas showed certain concentration degree, with value about 1.0. TWPTI, STGI was in the same case. It means that the radiation ability of producer services was kind of limited, in addition, the development of this industry could bring in revenue for local governments, and so local governments had incentives to set up regional barriers to keep boundary effects on producer services [8]. Secondly, from the growing trend, all the inner industries of producer services in the east, except LBI, improved in different degrees from 2004 to 2011. Producer services in Beijing kept agglomerating. In Beijing, FI enjoyed 7.36 percent average growth per year and TWPTI enjoyed 5.6 percent average growth per year, ranking highest among the provinces and autonomous regions. Moreover, its STGI enjoyed 3.51 percent average growth per year and ICSI enjoyed 4.82 percent average growth per year, ranking in the top three among China. These phenomena proved that producer services tended to agglomerate towards large urban centers. While, in the middle and west, taking ICSI as example, Shaanxi enjoyed 7.5 percent average growth per year, ranking highest among the provinces and autonomous regions, and Jilin enjoyed 7.17 percent average growth per year on Shaanxi's heels. Heilongjiang enjoyed 0.97 percent average growth per year, ranking in the top five among China. In the context that most of provinces and autonomous regions presented negative growth, the increase to a certain extent of information transmission, computer service industry and software industry in these central provinces presented that, with effects like the development of information technology, limitation of commercial land, rise 
of living cost, producer services that do not need to provide face-to-face services or long-distance communication depending on information technology by having "background" function, tended to move from the developed area in the east to the west. This phenomenon was caused by the development of new economy and appearance of flexible production mode. With the dispersion of economic development under the rise of network information technology, producer services that belong to traditional "background" function can keep away from central business districts of big cities to relocate in comparatively remote regions to cut business costs [17]. (See "Table III")

TABLE III. AGR OF LOCATION QUOTIENT OF PRODUCER SERVICE OF EVERY PROVINCE(\%) (2004-2011)

\begin{tabular}{|c|c|c|c|c|c|}
\hline & 1 & 2 & 3 & 4 & 5 \\
\hline Beijing & 5.601 & $4.82(3)$ & 7.3611 & -2.62 & $3.51(2)$ \\
\hline Tianjin & -3.57 & -9.07 & 1.19 & -1.47 & -5.11 \\
\hline Hebei & 0.41 & -2.48 & $1.62(5)$ & -0.70 & 1.35 \\
\hline Liaoning & 0.51 & 0.97 (4) & 0.64 & 2.88 & 2.95 (4) \\
\hline Shanghai & -0.27 & -0.23 & 0.55 & -3.20 & -6.37 \\
\hline Jiangsu & -2.06 & -0.58 & -0.13 & -1.82 & -0.39 \\
\hline Zhejiang & -3.18 & -1.86 & -4.53 & -0.52 & 0.06 \\
\hline Fujian & -0.66 & -2.69 & -3.42 & -2.19 & -1.07 \\
\hline Shandong & 0.94 & -1.50 & 0.83 & -3.14 & 0.66 \\
\hline Guangdong & 1.89 & -3.83 & -1.48 & 0.79 & 1.75 \\
\hline Guangxi & 1.18 & -1.12 & -1.32 & 1.71 & $2.96(3)$ \\
\hline Hainan & $2.51(4)$ & -2.28 & -1.44 & 5.09 (4) & -1.30 \\
\hline Shanxi & 1.60 & -0.39 & 1.80 (4) & -0.07 & -1.09 \\
\hline Inner Mongolia & $1.92(5)$ & 0.37 & 1.03 & -2.51 & -0.86 \\
\hline Jilin & -4.19 & $7.17(2)$ & -0.18 & -0.30 & 0.84 \\
\hline Heilongjiang & 0.87 & 0.97 (4) & $2.62(2)$ & -0.71 & 4.64(1) \\
\hline Anhui & -0.17 & -0.22 & 1.50 & -0.51 & $1.84(5)$ \\
\hline Jiangxi & -2.35 & -4.65 & -2.10 & $4.47(5)$ & -3.72 \\
\hline Henan & -1.20 & -3.01 & -2.16 & -2.20 & -2.05 \\
\hline Hubei & -1.50 & -0.69 & -1.70 & -11.28 & -0.08 \\
\hline Hunan & -2.08 & -1.99 & -0.80 & 0.41 & -1.61 \\
\hline Chongqing & -2.90 & -3.25 & 0.97 & $11.27(2)$ & -8.81 \\
\hline Sichuan & 0.42 & -3.21 & 0.46 & 3.76 & -1.53 \\
\hline Guizhou & 1.70 & -3.81 & 0.09 & -3.29 & 1.78 \\
\hline Yunnan & -1.47 & -5.58 & -4.04 & $6.72(3)$ & -2.78 \\
\hline Xizang & -3.42 & -11.19 & -3.40 & - & -1.70 \\
\hline Shaanxi & 0.05 & 7.50 (1) & 0.59 & -1.09 & -0.97 \\
\hline Gansu & -0.24 & -6.60 & -0.61 & -2.18 & -0.97 \\
\hline Qinghai & -2.46 & -6.54 & -2.60 & 0.26 & -1.80 \\
\hline Ningxia & $2.86(2)$ & -4.00 & $1.97(3)$ & 13.88(1) & 0.14 \\
\hline Xinjiang & $2.80(3)$ & -1.02 & -1.18 & 1.15 & -1.48 \\
\hline the East & 0.62 & 0.23 & 0.09 & -0.58 & 0.95 \\
\hline the Middle & -0.96 & -0.43 & -0.14 & -1.99 & -0.24 \\
\hline the West & -0.09 & -1.85 & -0.41 & 2.93 & -2.03 \\
\hline
\end{tabular}

a. Note: (1)(2)(3)(4) (5) mark provinces ranking in the top five in its industry. "1" represents transportation, warehousing and mail industry. "2" represents information transmission, computer service and software industry. "3" represents financial industry. "4" represents leasing and business service industry. "5" represents scientific research, technical service and geological prospecting industry.

\section{CONCLUSION}

This paper measured the concentration degree of China producer services by using Herfindahl-Hirschman Index, Location Quotient Index, EG Concentration Index and so on. By analyzing the evolutionary trend and law of development of concentration of China producer services from 2004 to 2011, fundamental conclusions come as follows: Firstly, the concentration degree of producer services is increasing in order to be close to customer, relative enterprises, and other service industries, and create common value, belief, and acquiescent understanding to make profits together. Governments can lead enterprises to agglomerate in certain areas to accelerate its development and drive the industrial structural transformation and optimization of modern service industry by taking supportive measures, delimiting industrial park, providing preferential policies and so on. Secondly, highly knowledge-intensive producer services that need to offer customized and complicated services tend to concentrate towards large urban centers from strength to strength. Industries like LBI, STGI are typical examples. The agglomeration of these industries is an important way to promote competitiveness of a city [18]. For example, business administration industry concentrates a lot of enterprise headquarters, especially multinational corporation headquarters that have huge power in the global economy, becoming the leading force of a city or region on international competition. Governments have to take measures to accelerate the agglomeration of legal service, audit and accounting service, consulting service, engineering technology service and so on towards large urban centers, 
[11] Li Pufeng, Li Tongsheng(2009). Spatial Patter And Mechanism Analysis of Producer Services In Xi'an. Urban Studies, 3,87-71.

[12] Dai Qinghua(2007). Present Situation Analysis and Countermeasures of Jiangsu Manufacturing Industry Agglomeration. Industrial Economics Research, 6,58-64.

[13] HeTianLong \&Wu JianGu(2014). The Empirical Study on the Pearl River Delta Producer Service. China Market, 41,66- 69.

[14] Zhou Dan(2011). Literature Review of Producer Service Industry Cluster Research. Laodong Baozhang Shijie, 12,82-83.

[15] Wu Sanmang, Li Shantong(2009). Empirical Analysis of Changing Trend of China's Manufacturing Industrial Agglomeration Degree, Journal of Shanxi Finance and Economics University, 12,40-48.

[16] Liang Ying, Luo Xiao (2006). Study of Financial Agglomeration Forming Mode: Global Views \& Local Choice. Journal of Nanjing University of Finance and Economics, 5, 16-1.

[17] Scott, A. J. (1988). New Industrial Spaces: Flexible Production Organization and Regional Development in North America and Western Europe (Vol. 3). Pion Ltd.

[18] Jay Kandampully(2001). The Dynamics of Service Clusters: A Phenomenon for Further Study.Managing Service Quality, 11, 134140.

[19] Li WenXiu(2008). Empirical Research on Service Industry Cluster in the United State of America. World Economy Study, 1, 79-83.

[20] Wang Min (2011). Financial Industry Agglomeration and Regional Financial Center Construction. South China Finance, 11, 36-40.

\section{REFERENCES}

[1] HE Jun(2008). Toward the Development of China Productive Service Sector. Modern Economic Science, 5:98-102+127.

[2] Alexander, I. (1979). Office Location and Public Policy. London: Longman.

[3] Daniels, P. W. (2002). Service Industries: A Geographical Appraisal. Routledge.

[4] Pandit, N. R., \& Cook, G. (2003). The Benefits of Industrial Clustering: Insights from the British Financial Services Industry at Three Locations. Journal of Financial Services Marketing, 7(3), 230245.

[5] Senn, L. (1993). Service Activities' Urban Hierarchy and Cumulative Growth. Service Industries Journal, 13(2), 11-22.

[6] Keeble, D., \& Nachum, L. (2002). Why do Business Service Firms Cluster? Small Consultancies, Clustering and Decentralization in London and Southern England. Transactions of the Institute of British Geographers, 27(1), 67-90.

[7] Stein,R., (2002). Producer Services, Transaction Activities, and Cities: Rethinking Occupational Categories in Economic Geography, European Planning Studies, 6,723-743.

[8] Gu NaiHua (2011). The Spillover Effect and Area Border of China Production Services Agglomeration. Finance \& Trade Economics,5,115-122.

[9] Chen Jianjun, Chen Guoliang(2009). Service Industry Development and Location Choice from an Agglomeration Perspective: A Latest Research Review. Journal of Zhejiang University (Humanities and Social Sciences),5,129-135.

[10] Gao YunSheng(2009). A Research on the Developing Pattern of Producer Services' Agglomeration Area in Shanghai. Beijing: Foreign Economic and Trade University Press. 